\title{
Analyzing Biology Students' Understanding Level on Plant Structure and Development Subject Based on Learning Style and Gender
}

\author{
Eliaumra \\ Biology Education Study Program \\ Sintuwu Maroso University \\ Poso.Indonesia \\ elia.umra@gmail.com \\ I Made Budiarsa \\ Biology Education Study Program \\ Tadulako University \\ Palu,Indoneia \\ Budiarsa_imade@yahoo.com
}

\author{
Ika Ista Dewi \\ SMP Negeri 4 Balesang \\ Donggala,Indonesia \\ Ikaistadewi5@gmail.com \\ Andi Wahab Pidu \\ SMP Negeri 1 Sindue \\ Donggala,Indonesia \\ Andiwahab2016@gmail.com \\ Ratman \\ Tadulako University \\ Palu, Indonesia \\ ratmanut@gmail.com
}

\begin{abstract}
The course of plant structure and development is a subject which requires skill and highlevel thinking skills in understanding the material. One of the factors affecting the level of understanding is learning the style. Characteristics diverse student including gender differences have an effect on learning styles. This study aims to describe the influence of different character to the understanding of plant structure and development course based on learning styles and gender. The data analyzed comes from the value of the final exams of plant structure and development course in the first semester of 2016/2017 and the student answers on the questionnaire index of learning style. with the dimensions of learning: active/ reflective, sensing/intuitive, visual/verbal, and sequential/ global. The findings of this study show that of the 18 male university students were $11.11 \%$ which is the familiar category have a tendency balanced on the dimensions of reflective learners, and female students from 38 people were $15.8 \%$ belong to the sensing learners group. Category understand was $38.89 \%$ of male students with a tendency balanced on the dimensions of active learners, and $42.1 \%$ female students belonging to the dimension of sensing learners. For the category of quite understand was $50 \%$ of male students belonging to the group dimension of visual learners, while the female students were $42.1 \%$ belong to the group of active learners. Thus there is the influence of a different character to the understanding of plant structure and development course by learning styles and gender.
\end{abstract}

Keywords: understanding level, plant structure, development subject, learning style, gender, biology students

\section{INTRODUCTION}

The course of Structure of Plant Development is a compulsory subject that must be programmed by students of Biology Education after completing prerequisite courses. This course discusses the basic concept of structure and development of the plant, covering structure, character, and development of plant organs. This course is divided into two forms of instructional activities, namely face-to-face lecturing and laboratory practicum; hence the students are required to possess high-level thinking skills to enable them to understand the course material in a structured and depth way.

Comprehension is the ability to grasp the meaning and significance of a learning material [1], as defined from Bloom's Taxonomy which is a taxonomy developed to classify instructional objectives. Bloom categorized the instructional objectives into three, which included as one part of the cognitive aspect since cognitive domain consists of knowledge, comprehension, application, analysis, synthesis, and evaluation. These six aspects of cognitive domains area hierarchy of cognitive thinking skills, starting from the lowest level to the highest one. In addition to that, understanding (comprehension) is an act of asking students to prove whether they understand the simple relationship between facts or concepts or not [2].

Understanding level as learning outcomes is a higher type of learning that knowledge level that can be divided into three categories [3]: (1) The lowest level of literal understanding, covering translating in literal level, defining and applying principles, (2) the second level is interpretation understanding, by connecting between the lowest parts already learned before with the next learned parts, or by connecting parts of the 
graphs with events, differentiating between what is principal and what is not principal, and (3) the third level is extrapolation understanding. Extrapolation understanding means that a person is able to see behind what is written, can estimate, can make predictions based on understanding and condition which is later described in form of ideas or symbols, and can make an inference by associating between implications and consequences [3].

Understanding also implies the ability to understand or know properly about something. This ability to understand is an important part of learning to know or studying something. Learning is not merely to know about something but also to expect good results. Someone can have the knowledge or knows something, but does not mean that he or she really understand it [4].

The ability to understand a learning material highly depends on external factors such as environmental and instrumental factors (e.g. teachers, curriculum and learning models) as well as internal factors (e.g. motivation, interests and learning styles). This person's ability to understand and absorb the lesson absolutely varies. A person's ability to understand and absorb the lessons certainly varies from fast, moderate, to very slow, resulting in different ways to understand information or learning material on the same topic. Learning style is a unique style of learning possessed by every student[5].

Learning style is a combination of how someone absorbs, then organizes and processes information [6.] Learning style is not only an aspect of facing information, seeing, listening to, writing and talking, but also an aspect of processing sequential information, analytical, global, or left-brain-right-brain, while the other aspect is by responding something (abstractly and concretely) in the learning environment. All students have different learning styles vary yet all styles are equally good for them [7]. Every style has its own strengths. In fact, we all have these three learning styles, although only one style dominates our learning [5],[6],[7].

Several scientists have studied learning styles, such as Felder with Solomon who first did the research in 1970 and continued by Felder with Silverman in 1988 with minor changes. Based on Felder and Silverman, students' learning styles can be categorized into four dimensions, namely processing (active or reflective), input (visual or verbal), perception (sensitivity or intuition) and understanding (sequential or global). To determine a student's learning style, Index of Learning Style questionnaire is commonly used to measure or determine student's learning style.

The followings are an explanation of each dimension of learning style[8]:

- Active-reflective dimension

Active: students learn best when actively learn the material through application and experiment. In addition to that, they tend to be interested in communicating with others and in-group to discuss the learned material.
Reflective: students prefer to think and reflect on the learning material. They choose independent learning or small group with close friends.

- Sensing or intuitive dimension

Sensing: students prefer studying facts and concrete learning material. They love solving problems with the standardized approach and tend to be more patient with details. They are more realistic, sensible and practical than the intuitive students. They prefer connecting material they learn with their real life.

Intuitive: students prefer to learn abstract learning materials, better able in finding possibilities, connection or relationships, and tend to be more innovative and creative than sensing students.

- Visual or verbal dimension

Visual: students with the characteristics of being able to remember what they have seen.

Verbal: students with the characteristic of preferring material with textual representation, such as text or narration.

- Sequential or global dimension

Sequential: Sequential: students learn to move through small increased steps, and hence have a linear progress. They tend to follow logical steps in finding a solution.

Global: students tend to use holistic thinking process and learn through a big leap. They tend to absorb learning material randomly without realizing its connection between others, yet after they gain enough material they are able to get the whole or thorough picture of all learning materials.

Everyone has their own learning styles. Thus, it is important for the educator to understand these differences instead of forcing the students to adopt one similar style only. Regarding this, innovation in education today is in form of efforts to introduce students with different learning styles. That is to say, many people especially numerous researchers have laid a strong foundation in order to understand the differences between individuals. Based on some research findings in general, men have better ability in visual-spatial tasks compared to women. Conversely, women seem to be more capable in some verbal skills, though not all. For example, girls in average have a larger stock of vocabulary and are able to express their thoughts quicker than boys do [9].

Not only that gender causes only a less difference between visual-spatial, verbal and mathematical performance, but the researchers also find out that such difference is getting smaller and smaller in recent years. In other words, boys and girls are equal in their academic achievement. Therefore, in general, we should expect boys and girls to have equal academic performance in various learning subjects. Furthermore, this also gives an illustration that gender difference brings certain characteristics to personality too and shows that different gender can have different thoughts thus resulting in different learning styles as well [9]. 
Gender differences in academic achievement have been reported by Eddy and Brownell, who argue that there are differences of academic ability between men and women with an indicator of the number of students who do not continue their education at the Faculty of Science and Technology, Engineering and Math. The gap in academic achievement between students can be considered as an important factor behind the reason of why female students tend to drop out from the faculty than male students. However, this finding conflicts with another research finding that compares between female students who drop out of college with those who do not at the Faculty of Science, Technology, and Mathematics, which does not have any significant difference in their academic performance. Furthermore, the findings of this study, which evaluates the academic performance of various disciplines including engineering, biology, chemistry, physics, and mathematics, do not see a consistent gender gap in academic achievement of all these disciplines [10].

Another study [11] proves that "this stereotype favorable to both genders shows an improvement of the girls' reputation in mathematics." They mean that gender stereotype has benefited both male and female students, which shows an increase of female students' reputation in mathematics. It means that female students with feminine traits have higher mathematics performance than male students with masculine traits has, so it becomes obvious that there are differences in mathematics achievement between students with feminine and masculine traits. In addition to that, [12] states that "gender bias is stereotypical views and differential treatment of males and females, often favoring one gender over the other". In other words, gender bias is the view of stereotypes and discrimination against men and women, who treat one gender as inferior to the other one. Thus, teachers who treat girls as inferior to boys have created a gender bias in their class [11][12][13].

This study aims to describe the influence of different characters to the understanding of materials on the structure of plant development based on their learning styles and gender differences

\section{METHOD}

This research is qualitative in nature. A case study is a thorough investigation of a person or group of people being treated as a case to give proper and complete illustration [14]. According to Tellis,descriptive study case then requires researchers to start with a descriptive theory or to deal with the problems that may arise during the research. Later, some parts will be analyzed, and the data are taken from each part and will be compared with each other under ideal theoretical pattern. This requires the researchers to conduct in-depth exploration that is also limited by time and activities [15].

The population in this study was students of Biology Education in the Faculty of Teacher Training and Education at Sintuwu Maroso University, who enrolled in the course of Structure of Plant Development in the odd semester of academic year 2016/2017. The sample of this study was 56 students as total sampling. The data for level of understanding was obtained from students' final examination results after completing the course, which was categorized into four categories, namely totally understand the range of score $\geq 80$, understand the range of score 68-79, less understand the range of score 56-67, and do not understand the range of score $\leq 55$ [16].

The data of learning styles were obtained through Index of Learning Styles [17]. The questionnaire consists of 44 items, translated to obtain information about learning styles owned by a person, where the information was categorized into four groups of learning styles, namely (1) active and reflective learners, (2) sensing and intuitive learners, (3) visual and verb learners, and (4) sequential and global learners.

The obtained data through questionnaires were processed and converted into quantitative data to provide data description into ILS Scoring Sheet (Figure 1), in order to obtain students' total responses according to four groups of learning styles [17]. The calculation of ILS Scoring Sheet is displayed in ILS Report Form (Figure 2) to provide an overview of the trend of student's learning style [17].

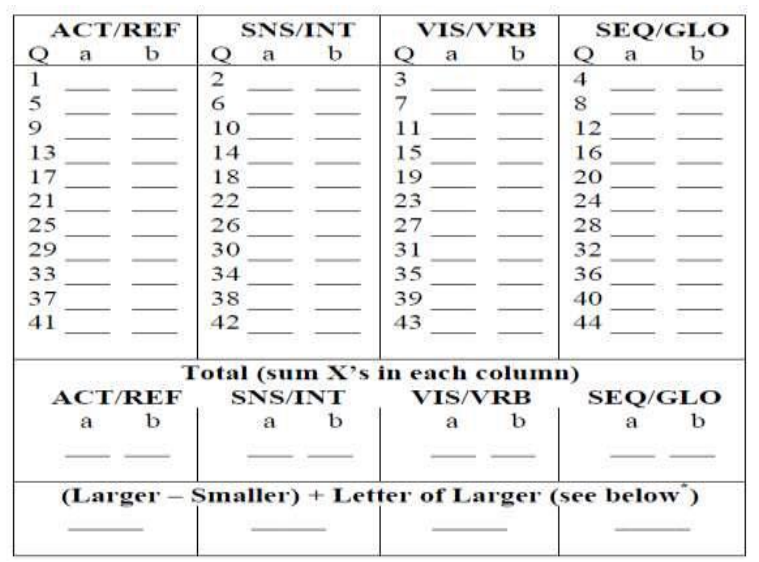

Fig. 1. ILS Scoring Sheet

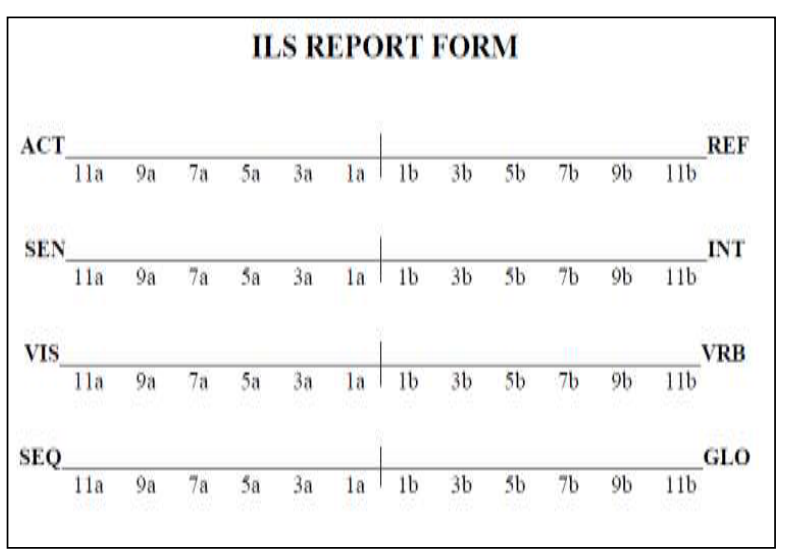

Fig. 2. ILS Report Form

To determine the trend of students' learning styles, ILS Report Form can be categorized as follows: 
- If the score is on a scale of 1-3, then the student is in the position of balance between the two dimensions of learning style.

- If the score is on the scale of 5 or 7 , then the student is in a position of moderate or medium on one dimension of learning styles on the scale and it will be easier for the student to learn in the scope of teaching that supports this learning dimension.

- If the score on the scale of 9 or 11 , then the student has a very strong tendency to one-dimension a learning style on the scale. Students are likely to encounter real difficulties in learning environments that do not support this tendency.

\section{RESULT AND DISCUSSION}

\section{A. Level of Understanding based on Gender}

The results of data analysis on the male students' level of understanding on the material of structure of plant development are displayed in Table 1.

TABLE I. LEVEL OF Understanding of MALE StUdents ON THE MATERIAL OF STRUCTURE OF PLANT DEVELOPMENT

\begin{tabular}{|c|c|c|c|c|}
\hline No. & $\begin{array}{c}\text { Interval of } \\
\text { Score }\end{array}$ & Category & Frequency & Percentage \\
\hline 1. & $80-100$ & $\begin{array}{c}\text { Totally } \\
\text { understand }\end{array}$ & 2 & 11.11 \\
\hline 2. & $68-79.99$ & Understand & 7 & 38.89 \\
\hline 3. & $56-67.99$ & $\begin{array}{c}\text { Fairly } \\
\text { understand }\end{array}$ & 9 & 50 \\
\hline 4. & $45-55.99$ & $\begin{array}{c}\text { Less } \\
\text { understand }\end{array}$ & 0 & 0 \\
\hline 5. & $<44.99$ & $\begin{array}{c}\text { Not } \\
\text { understand }\end{array}$ & 0 & 0 \\
\hline & Total & & 18 & 100 \\
\hline
\end{tabular}

Based on these data in Table 1, it can be seen that the highest level of understanding of male students is in the category of fairly understand (50\%) and the lowest level is totally understood (11.11\%).

The female students' level of understanding on the material of structure of plant development is shown in Table 2.

TABLE II. LEVEL OF UNDERSTANDING OF FEMALE STUDENTS ON THE MATERIAL OF StRUCTURE OF Plant DEVELOPMENT

\begin{tabular}{|c|c|c|c|c|}
\hline No & $\begin{array}{c}\text { Interval } \\
\text { of Score }\end{array}$ & Category & Frequency & Percentage \\
\hline 1. & $80-100$ & $\begin{array}{c}\text { Totally } \\
\text { understand }\end{array}$ & 6 & 15,8 \\
\hline 2. & $68-79,99$ & Understand & 16 & 42,1 \\
\hline 3. & $56-67,99$ & $\begin{array}{c}\text { Fairly } \\
\text { understand }\end{array}$ & 16 & 42,1 \\
\hline 4. & $45-55,99$ & $\begin{array}{c}\text { Less } \\
\text { understand }\end{array}$ & 0 & 0 \\
\hline 5. & $<44,99$ & $\begin{array}{c}\text { Not } \\
\text { understand }\end{array}$ & 0 & 0 \\
\hline & Total & & 38 & 100 \\
\hline
\end{tabular}

Based on Table 2, that the highest levels of understanding of female students are in the category of understanding and fairly understand (both are 42.1\%) and the lowest level is totally understood $(15.8 \%)$.

The research findings obtained from the students' final test score after completing the course ofthestructure of plant development shows differences on their level of understanding the material. Tables 1 and 2 show that percentage of female students' level of understanding of the material is higher $(15,8 \%)$ than the male students in the categorize of totally understand. This can be interpreted that the female students' level of understanding is better than male students have. Also, in the category of understanding, the female students' level of understanding is better than the male students have. While in the category of fairly understand, the percentage of the male students is higher than of the female students. To conclude, the female students have ahigher level of understanding the material of structure of plant development than the male students have.

This is consistent with Conger and Long's research findings who also find differences in the academic achievement between male and female students. Their findings show that male students' academic achievement is lower than female students have in their first semester at college. Male students earned 0.43 credit fewer than the female students did in the first semester, and they even earned fewer credits in the next semester, thus at the end of the sixth semester, male students lacked 6.6 cumulative credits than female students. Moreover, male students also got lower scores than female students did every year [18].

\section{B. Learning Styles based on Gender}

The data on learning styles based on gender are shown in the following table 3 and 4 .

TABLE III. LEARning Style of Male Students

\begin{tabular}{|c|c|c|c|c|c|c|c|c|c|}
\hline $\begin{array}{c}\text { Category } \\
\text { of } \\
\begin{array}{c}\text { Learning } \\
\text { Style }\end{array}\end{array}$ & \multirow{2}{*}{ Scale } & \multicolumn{7}{|c|}{ Total Students on the Learning Styles } \\
\cline { 3 - 10 } Dimension & Act & Ref & Sen & Int & Vis & Vrb & Seq & Glo \\
\hline Balanced & $1-3$ & 16 & 2 & 7 & 3 & 7 & 4 & 13 & 4 \\
\hline Moderate & $5-7$ & - & - & 7 & - & 3 & 2 & 1 & - \\
\hline Strong & $9-11$ & - & - & 1 & - & 1 & 1 & - & - \\
\hline Total & & 16 & 2 & 15 & 3 & 11 & 7 & 14 & 4 \\
\hline
\end{tabular}

Based on Table 3, it can be seen that the trend of male students' learning style is categorized as active learners dimension. Table 4 shows the trend of female students' learning style. 
TABLE IV. LEARNING STYLE OF FEMALE StUdENTS

\begin{tabular}{|c|c|c|c|c|c|c|c|c|c|}
\hline $\begin{array}{c}\text { Category } \\
\text { of } \\
\begin{array}{c}\text { Learning } \\
\text { Style }\end{array}\end{array}$ & \multirow{2}{*}{ Scale } & \multicolumn{7}{|c|}{ Total Students on the Learning Styles } \\
\cline { 3 - 11 } Dimension & Act & Ref & Sen & Int & Vis & Vrb & Seq & Glo \\
\hline Balanced & $1-3$ & 26 & 4 & 16 & 3 & 13 & 10 & 20 & 10 \\
\hline Moderate & $5-7$ & 4 & 2 & 12 & - & 11 & 2 & 5 & 3 \\
\hline Strong & $9-11$ & 2 & - & 7 & - & 2 & 1 & - & - \\
\hline Total & & 32 & 6 & 35 & 3 & 26 & 12 & 25 & 13 \\
\hline
\end{tabular}

Based on Table 4, it can be seen that the trend of female students' learning style is categorized as sensing learners dimension.

Based on the analysis of data obtained from the questionnaires on students' index of learning style, there are differences in learning styles of male and female students, where male students tend to belong to active learners dimension. It means that male students prefer to work with other students to infer about what will be asked during examination and to understand how to reply. Students who belong to this learning style dimension will learn better that way. Female students tend to belong to sensing learners dimension, means that female students learn better by remembering and understanding information through seeing the connection of the material with their real life. If these students enroll in courses that teach the abstract and theoretical material, they are more likely to find it difficult. Asking peers, seniors or lecturers for examples of concept and procedure and finding out the application of such concept can become solutions to solve those difficulties.

Differences of a trend in learning styles are resulted from male students' behaviors who are visual, tend to work together with their friends to make them more motivated, and learn without listening. On the contrary, female students tend to be good listeners in learning and prefer quite an atmosphere to learn [19]. Kendall andTannen shows that male students prefer to perform learning tasks that involve talking in public setting since this can make them feel more obliged to build or maintain their position in the group. On the other hand, female students prefer to speak in a private setting since they see conversation as an important way to maintain relationships [20].

\section{Students' Level of Understanding based on Learning Styles and Gender}

The results of data analysis on the students' level of understanding on the material of structure of plant development based on their learning styles and gender are displayed in Table 5.
TABLE V. STUDENTS' LEVEL OF UNDERSTANDING BASED ON LEARNING STYLES AND GENDER

\begin{tabular}{|c|c|c|c|c|}
\hline No. & $\begin{array}{c}\text { Level of } \\
\text { Understanding }\end{array}$ & Gender & Learning Style & Percentage \\
\hline \multirow{2}{*}{1.} & \multirow{2}{*}{$\begin{array}{c}\text { Totally } \\
\text { understand }\end{array}$} & Male & $\begin{array}{c}\text { Reflective } \\
\text { Learner }\end{array}$ & 11.11 \\
\hline & & Female & Sensing Learner & 15.80 \\
\hline \multirow{2}{*}{2.} & \multirow{2}{*}{ Understand } & Male & Active Learner & 38.89 \\
\hline & & Female & Sensing Learner & 42.10 \\
\hline \multirow{2}{*}{3.} & \multirow{2}{*}{$\begin{array}{c}\text { Fairly } \\
\text { understand }\end{array}$} & Male & Visual Learner & 50.00 \\
\hline & & Female & Active Learner & 42.10 \\
\hline
\end{tabular}

Based on Table 5, under totally understand category as the level of understanding, $11.11 \%$ of 18 male students have a tendency to be categorized in reflective learners dimension, while $15.8 \%$ of 38 female students are in sensing learners dimension. Next, under the understand category as the level of understanding, $38.89 \%$ male students have a moderate tendency inactive learners dimension, while $42.1 \%$ female students belong to sensing learners dimension. Later, under the fairly understand category as the level of understanding, $50 \%$ male students are categorized in visual learners dimension while 42.1 female students belong to active learners dimension.

The research findings presented in Table 11 shows differences of understanding the material based on learning styles and gender. Under the category of totally understand, the trend of male students' learning style is reflective learners, which means that the male students prefer to think about the material first and prefer to work alone, while the trend of female students' learning style is sensing learners, which means that they prefer learning facts to concepts. They often prefer solving problems with the well-prepared method and do not like complexity and element of surprise.

For the category of understanding, the trend of male students' learning styles is active learners, which means that they tend to know and understand information best by actively doing something such as discussing, applying something, or explain it to others. They are more likely to enjoy working in groups. The trend in female students' learning styles is sensing learners who prefer to learn about facts, and this learning style has contributed to their better level of understanding in understanding the material on the structure of plant development since this material applies anacontextual approach that is related to teaching real facts about plant development.

In the category of fairly understand, the trend of male students' learning styles is visual learners, where they are able to remember well if they are assisted with pictures, graphs and diagrams, flowcharts, schedules, movies, and demonstrations. The trend of female students' learning styles is active learners who prefer group learning. According to toTatarinceva, female students are better than male students in completing language tasks such as remembering verbal information, faces, names, 
and object locations. As for male students, they do better in doing tasks related to showing directions [21].

\section{CONCLUSIONS}

In conclusion, based on the research findings and discussions, this research reveals that:

1) Female students have a better level of understanding the material of structure of plant development compared to male students.

2) The trend of male students' learning styles is active learners, while female students' learning style is sensing learners.

3) There are differences on the level of understanding the material of structure of plant development based on students' learning styles and gender.

\section{ACKNOWLEDGMENT}

The authors would like to thank rector of Sintuwu Maroso University for support financial this study and wealso to thankthehead of science education courses Prof. Daud for advice in writing of this manuscript.

\section{REFERENCES}

[1] W. S. Winkel, Psikologi Pengajaran, Revisi. Jakarta: Grasindo Persada, 2005

[2] S. Arikunto, Dasar-Dasar Evaluasi Pendidikan, Ketiga. Jakarta: Bumi Aksara, 2013.

[3] N. Sudjana, Penilaian Hasil Proses Belajar Mengajar. Bandung: Remaja Rosdakarya, 2009.

[4] Eliaumra, "Pemahaman Materi Analisis Vegetasi Dengan Menggunakan Metode Transek Pada Mata Kuliah Ekologi Tumbuhan Mahasiswa Program Studi Pendidikan Biologi," J. Kependidikan, vol. 8, no. 1, pp. 79-105, 2015.

[5] I. M. W. Jagantara et al., "( Project Based Learning ) Terhadap Hasil Belajar Biologi Ditinjau Dari Gaya Belajar Siswa Sma,"e-Journal PPs Universitas Pendidikan Ganesha, vol. 4, no. 3, pp. 1-13, 2014.

[6] B. De Porter and M. Hernacki, Quantum Leraning. Edisi Revisi. Bandung: Kaifa, 2000

[7] B. De Porter, M. Reardon, and S. Nourie, Quantum Teaching. Bandung: Kaifa, 2002

[8] Marzoan, "Gaya Belajar Felder-Silverman dan Hasil Belajar Sains di Sekolah Dasar ( SD )," in Seminar Asean 2th Psychology and Hmanity, Forum Psikologi UMM, 2016, no. 3, pp. 19-20.

[9] A. K. Damayanti, "Gaya Belajar Ditinjau dari Tipe Kepribadian dan Jenis Kelamin,” J. Psikol. Indones., vol. 1, no. 2, pp. 88-98, 2012.

[10] S. L. Eddy and S. E. Brownell, "Beneath the numbers: A review of gender disparities in undergraduate education across science ,technology,engineering, and math disciplines," Phys. Rev. Phys. Educ.
Res., vol. 12, no. 20106, pp. 1-20, 2016.

[11] D. Martinot, C. Bages, and M. Desert, "French Children's Awareness of Gender Stereotypes About Mathematics and Reading When Girls Improve Their Reputation in Math _ SpringerLink," Sex Roles, vol. 66, no. 3, pp. 210-219, 2011.

[12] E. Slavin, R, Educational Psychology: Theory and Practice. Boston,MA: Pearson Education, Inc., 2013.

[13] A. Hidayat and S. Dwiningrum, "Pengaruh Karakteristik Gender dan Motivasi Belajar Terhadap Prestasi belajar Matematika Siswa SD," J. Prima Edukasia, vol. 4, no. 1, pp. 32-45, 2016.

[14] G. Marczyk, D. De Matteo, and D. Fistenger, Essential of Research Design. NJ: John Wiley \& Sons, Inc., 2005.

[15] W. . Tellis, “'Introduction to Case Study '," Quant. Rep., vol. 3, no. 2, pp. 1-14, 1997.

[16] Unsimar, Pedoman Akademik. Poso: Lembaga Penjaminan Mutu, Unsimar, 2011

[17] R.Felder and S.Soloman, "Index of Learning Styles ( ILS ) Learning Style Questionnaire." North Carolina State University, USA, pp. 1-12, 2002.

[18] D. Conger and M. C. Long, "Why are Men Falling Behind ? Gender Gaps in College Performance and Persistence," Ann.Am.Acad.Pol.Soc.Sci., vol. 627, no. 184, pp. 1-34, 2010.

[19] A. Tatarinceva, "Influence Of The Gender Factor On A Student' S Learning Style And Achievements In Language Learning." Transport and Telecommunication Institute, Latvia, pp. 64-71, 2006.

[20] S. Kendall and D. Tannen, "Discourse and Gender," in The Handbook of Discourse Analysis, 2nd Edition, UK: John Wiley \& Sons, Ltd., 2015 , p. 640

[21] C. Viriya and S. Sapsirin, "Gender Differences In Language Learning Style And Language Learning Strategies Chayata Viriya \& Sutthirak Sapsirin Perbedaan-Perbedaan Gender Dalam Gaya Belajar Bahasa Dan Strategi-Strategi Belajar Bahasa,"Indonesian Journal of AppliedLinguistics, vol. 3, no. 2, pp. 77-88, 2014. 